\title{
Regio- and Stereoselective Generation of Enolates from Aminohydroxyacetone Derivatives ${ }^{\dagger}$
}

\author{
Ji Eun An and Kwan Soo Kim* \\ Center for Bioactive Molecular Hybrids and Department of Chemistry, Yonsei University, Seoul 120-749, Korea \\ ${ }^{*}$ E-mail: kwan@yonsei.ac.kr \\ Received March 22, 2011, Accepted April 6, 2011
}

Key Words : Aminohydroxyacetone, Aldol reaction, Silyl enol ether, Dihydroxyacetone

1-Amino-3-hydroxyacetone (AHA, 1) is the deoxyaminoderivative of 1,3-dihydroxyacetone (DHA, 2). Nature utilizes dihydroxyacetone phosphate (DHAP), a phosphorylated form of DHA, as the donor substrate in enzymatic aldol reactions for the synthesis of ketose sugars. ${ }^{1}$ Although DHAPdependent aldolases possess an almost perfect ability to control the stereochemistry of aldol products, ${ }^{2}$ they are relatively unstable and do not accept many useful aldehydes as acceptor substrates. The chemical aldol reaction of protected DHAs with aldehydes, therefore, attracted a great deal of attention as a useful supplement or alternative to the enzymatic aldol reaction of DHAP. Since the first report on the chemical aldol reaction of protected DHAs with aldehydes by our laboratory, ${ }^{3}$ there have been numerous reports on diastereoselective and enantioselective aldol reactions of DHA derivatives with various aldehydes. ${ }^{4}$ Consequently, the DHA unit is now well recognized as a versatile $\mathrm{C}_{3}$ building block in organic synthesis.<smiles>NCC(=O)CO</smiles><smiles>O=C(O)CO</smiles>

Aldol reactions of AHA derivatives with aldehydes, on the other hand, would provide useful aminoketose sugars or precursors for other important natural products containing the amino group. However, neither enzymatic nor chemical aldol reactions of AHA derivatives have been explored although a few AHA derivatives have been synthesized before. ${ }^{5}$ Aldol reactions of AHA derivatives are inherently more complex than those of symmetric DHA derivatives: there would be two stereoisomeric enolates, $Z$ - and $E$-enolates, possible by the deprotonation of DHA derivatives whereas four isomeric enolates possible from AHA derivatives due to additional regioisomers. In order to establish the reliable enantioselective chemical aldol reactions of AHA derivatives with aldehydes, the development of the method for the regioand stereoselectve generation of enolates from appropriately protected AHAs is essential. Herein we describe the synthesis of new protected AHAs and reveal the method for the regioselective and stereoselective generation of their enolates.

${ }^{\top}$ This paper is dedicated to Professor Eun Lee on the occasion of his honourable retirement.
Cerium chloride promoted regioselective ring opening ${ }^{6}$ of commercially available racemic benzyl glycidyl ether $\mathbf{3}$ using sodium azide in refluxing acetonitrile/water afforded known azidopropanol $\mathbf{4}^{7}$ in high yield as shown in Scheme 1. Oxidation of the alcohol 4 with Dess-Martin periodinane ${ }^{8}$ gave azidoketone $\mathbf{5}$ in almost quantitative yield. Reduction of the azido group of $\mathbf{4}$ with triphenylphosphine in the presence of water ${ }^{9}$ in THF and the subsequent protection of the amino group of the resulting crude amino alcohol with phthalic anhydride in refluxing toluene provided phthalimidopropanol 6 in 77\% yield in two steps. Oxidation of 6 with PCC afforded $N$-phthaloyl-O-benzyl-AHA 7 in $86 \%$ yield. The epoxide ring of $\mathbf{3}$ was also opened with dibenzylamine in the presence of calcium triflate ${ }^{10}$ in refluxing acetonitrile, providing dibenzylaminopropanol 8 in $91 \%$ yield. Oxidation of 8 with DMSO and oxalyl chloride gave $N, N$-dibenzyl- $O$ benzyl-AHA 9 in $70 \%$ yield.

Treatment of the azidoketone 5 with $\mathrm{KN}\left(\mathrm{SiMe}_{3}\right)_{2}(1.2$ equiv) in THF at $-78{ }^{\circ} \mathrm{C}$ for $10 \mathrm{~min}$ followed by the reaction of the resulting enolate with TBDMSCl (1.5 equiv) at -78 ${ }^{\circ} \mathrm{C}$ for $30 \mathrm{~min}$ afforded $Z$-silyl enol ether $\mathbf{1 0}$ in $39 \%$ yield as shown in Scheme 2. Although the reaction was regio- and stereoselective, a substantial amount of decomposition products were generated. We were not able to suppress the generation of the decomposition products under various different reaction conditions. In fact, it was reported that some of $\alpha$-azido ketones were highly base-sensitive and undergo base-promoted loss of nitrogen to form $\alpha$-iminoketones. ${ }^{11}$ Deprotonation of phthalimidoketone 7 with $\mathrm{KN}\left(\mathrm{SiMe}_{3}\right)_{2}$ (1.2 equiv) in THF at $-78{ }^{\circ} \mathrm{C}$ for $10 \mathrm{~min}$ followed by the reaction of the resulting enolate with $\mathrm{TBDMSCl}(1.5$ equiv) at $-78{ }^{\circ} \mathrm{C}$ for $2 \mathrm{~h}$ provided $Z$-silyl enol ether 11 in $51 \%$ yield. The reaction of 7 was much cleaner than that of azidoketone 5: the amount of the decomposition products was much less and a small amount of starting material 7 was recovered. The regioselective removal of the proton at $\mathrm{C}-1$ near the phthalimido group and the stereoselective generation of the Z-enolate resulted in the exclusive formation of $\mathbf{1 1 .}$

On the other hand, the deprotonation of dibenzylaminoketone 9 occurred at C-3 near the benzyloxy group unlike the deprotonation of phthalimidoketone 7 . Thus, the deprotonation of 9 with $\mathrm{KN}\left(\mathrm{SiMe}_{3}\right)_{2}\left(1.2\right.$ equiv) in $\mathrm{THF}$ at $-78^{\circ} \mathrm{C}$ for 10 $\mathrm{min}$ and the subsequent reaction of the resulting enolate with 


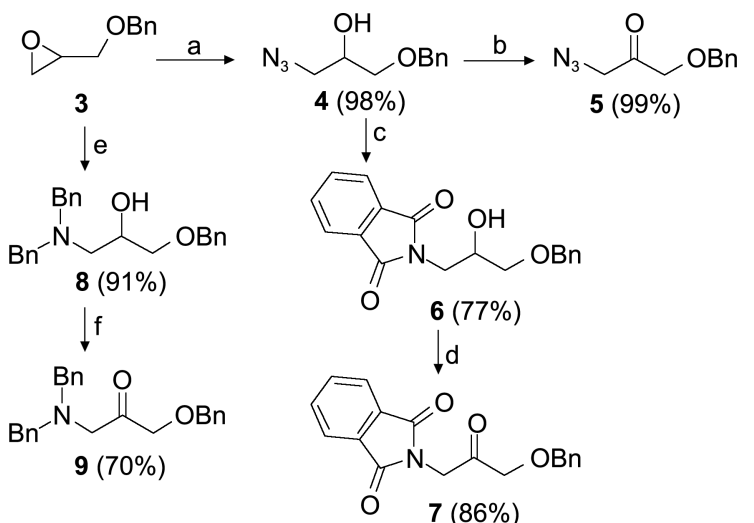

Reagents and conditions:

(a) $\mathrm{NaN}_{3}, \mathrm{CeCe}_{3} \cdot 7 \mathrm{H}_{2} \mathrm{O}, \mathrm{CH}_{3} \mathrm{CN}$, reflux; (b) Dess-Martin periodinane $\mathrm{CH}_{2} \mathrm{Cl}_{2}$, rt; (c) (i) $\mathrm{Ph}_{3} \mathrm{P}, \mathrm{H}_{2} \mathrm{O}$, THF, rt, (ii) phthalic anhydride, toluene, reflux; (d) $\mathrm{PCC}, \mathrm{CH}_{2} \mathrm{Cl}_{2}$, rt; (e) dibenzylamine, $\mathrm{Ca}(\mathrm{OTf})_{2}$, $\mathrm{CH}_{3} \mathrm{CN}$, reflux; (f) $(\mathrm{COCl})_{2}, \mathrm{DMSO}, \mathrm{Et}_{3} \mathrm{~N}, \mathrm{CH}_{2} \mathrm{Cl}_{2},-78$ to $0{ }^{\circ} \mathrm{C}$

\section{Scheme 1}

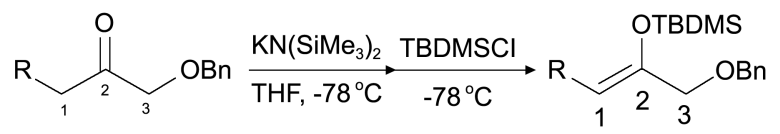

$5 \mathrm{R}=-\mathrm{N}_{3}$ $10 \mathrm{R}=-\mathrm{N}_{3}(39 \%)$<smiles></smiles><smiles>[R5]N1C(=O)c2ccccc2C1=[R5][H]</smiles>

Scheme 2

TBDMSCl ( 1.5 equiv) at $-78^{\circ} \mathrm{C}$ for $2 \mathrm{~h}$ provided $Z$-enolate 12 in $69 \%$ yield as shown in Scheme 3. The reaction was completely regioselective and stereoselective, providing enol ether 12 exclusively and no other isomeric enol ethers were detected in the reaction mixture. Based on ${ }^{1} \mathrm{H} /{ }^{13} \mathrm{C} /$ COSY/HSQC/HMBC NMR data, the location of the double bond in $\mathbf{1 2}$ was determined while the stereochemistry of the double bond in $\mathbf{1 2}$ was assigned by examining its NOESY spectrum. Thus, strong NOE cross-peaks between $\mathrm{H}-1$ and $\mathrm{H}-3$ and between $\mathrm{H}-3$ and benzylic $\mathrm{H}$ of $\mathbf{1 2}$ were observed and their intensity were almost same. It is known that the NOE between $\mathrm{H}-1$ and $\mathrm{H}-3$ is observed in the Z-silyl enol ether obtained from dibenzyl-DHA but not in the $E$-silyl enol ether. ${ }^{3}$ Similarly, the regiochemistry and stereochemistry of the double bond in enol ethers $\mathbf{1 0}$ and $\mathbf{1 1}$ were also determined based on their HSQC, HMBC, and NOSEY NMR data.

The preferred formation of Z-silyl enol ethers from all three ketones $\mathbf{5}, \mathbf{7}$, and 9 could be explained by assuming the chelation of the metal ion with the heteroatoms in the enolates. The five-membered ring chelates by coordination of the potassium ion to two oxygen atoms or to an oxygen and a nitrogen atoms would make the $Z$-enolates more stable.

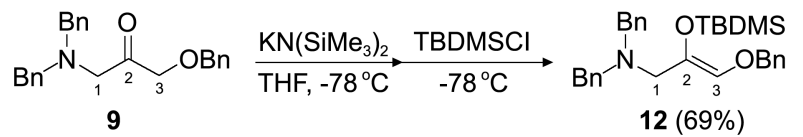

Scheme 3
Because the azido and phthalimido groups are probably more electron-withdrawing and the dibenzylamino group is less electron-withdrawing than the benzyloxy group, ${ }^{12}$ the protons at $\mathrm{C}-1$ near the nitrogen are more acidic than those at C-3 in both 5 and 7 while the protons at C-3 near the oxygen has the higher acidity than that at $\mathrm{C}-1$ in $\mathbf{9}$. In addition, the sterically demanding dibenzylamino group might also reduce the kinetic acidity of the C-1 protons of the ketone 9 .

The result indicates that $Z$-enolates are formed stereoselectively from AHA derivatives by the chelation-controlled reaction and that the regiochemistry of the enolates from the AHA derivatives can be controlled by the simple choice of the appropriate protecting group for the amino group. Further studies are underway to explore the catalytic asymmetric synthesis of aminoketose sugars from AHA derivatives.

Acknowledgments. This work was supported by the National Research Foundation (NRF) grant funded by the Korea government (MEST) through the Center for Bioactive Molecular Hybrids (NO. R11-2003-019-00000-0).

\section{References}

1. Calvin, M. Angew. Chem. Int. Ed. Engl. 1962, 1, 65-75.

2. (a) Jones, J. K. N.; Sephton, H. H. Can. J. Chem. 1960, 38, 753760. (b) Wong, C.-H.; Whitesides, G. M. Enzymes in Synthetic Organic Chemistry; Pergamon: Oxford, 1994; Chapter 4. (c) Fessner, W.-D.; Walter, C. Top. Curr. Chem. 1996, 184, 97-194. (d) Machajewski, T. D.; Wong, C.-H. Angew. Chem. Int. Ed. 2000, 39, 1352-1375.

3. Kim, K. S.; Hong, S. D. Tetrahedron Lett. 2000, 41, 5909-5913.

4. For selected references on the chemical aldol reactions of DHA derivatives, see: (a) Enders, D.; Voith, M.; Lenzen, A. Angew. Chem. Int. Ed. 2005, 44, 2-23. (b) Markert, M.; Mulzer, M.; Schetter, B.; Mahrwald, R. J. Am. Chem. Soc. 2007, 129, 72587259. (c) Utsumi, N.; Imai, M.; Tanaka, F.; Ramasastry, S. S. V.; Barbas, C. F., III. Org. Lett. 2007, 9, 3445-3448. (d) Markert, M.; Mahrwald, R.; Chem. Eur. J. 2008, 14, 40-48. (e) Luo, S.; Xu, H.; Zhang, L.; Li, J.; Cheng, J.-P. Org. Lett. 2008, 10, 653-656. (f) Ramasastry, S. S. V.; Albertshofer, K.; Utusmi, N.; Barbas III, C. F. Org. Lett. 2008, 10, 1621-1624. (g) Enders, D.; Marine, A. A. J. Org. Chem. 2008, 73, 7857-7870. (h) Yang, H.; Carter, R. G. Org. Lett. 2008, 10, 4649-4652. (i) Li, J.; Luo, S.; Cheng, J.-P. J. Org. Chem. 2009, 74, 1747-1750. (j) Kumar, A.; Singh, S.; Kumar, V.; Chimni, S. S. Org. Biol. Chem. 2011, Advance Article, DOI: 10. 1039/C0OB00898B.

5. Bischofberger, N.; Waldmann, H.; Saito, T.; Simon, E. S.; Lees, W.; Bednarski, M. D.; Whitesides, G. M. J. Org. Chem. 1988, 53, 3457-3465.

6. Meyer, O.; Ponaire, S.; Rohmer, M.; Grosdemange-Billiard, C. Org. Lett. 2006, 8, 4347-4350.

7. Boruwa, J.; Borah, J. C.; Kalita, B.; Barua, N. Tetrahedron Lett. 2004, $45,7355-7358$.

8. Dess, D. B.; Martin, J. C. J. Org. Chem. 1983, 48, 4155-4156.

9. Vaultier, M.; Knouzi, N.; Carrié, R. Tetrahedron Lett. 1983, 24, 763-764.

10. Cepanec, I.; Litviæ, M.; Mikuldaš, H.; Bartolinèiè, A.; Vinkoviè, V. Tetrahedron 2003, 59, 2435-2439.

11. (a) Boyer, J. H.; Canter, F. C. Chem. Rev. 1954, 54, 1-57. (b) Edwards, O. E.; Purushothaman, K. K. Can. J. Chem. 1964, 42, 712-716.

12. For the field/inductive parameter $F$, see: Hansch, C.; Leo, A.; Taft, R. W. Chem. Rev. 1991, 91, 165-195. 